\title{
RESOURCES OF MIGRATION GROWTH HAVE RUN DRY ${ }^{1}$
}

\author{
Yu.Florinskaya, N.Mkrtchan
}

Net migration has been contracting. Resource for long-term migration including internal one has run dry. At the same time, the number of foreign nationals temporarily staying on the territory of Russia is falling. Although reasons for these processes differ -in the first instance, the question is partly about static effect and in the second-most likely about tightening migration legislation. On the whole, one may talk about the fact that migration stops contributing seriously to the demographic situation and to the labor market.

\section{Long-term migration}

The number of long-term migrants who arrived in Russia in 2015 constituted around 600,000 persons and the number of those who left Russia exceeded 350,000 persons. At the same time, compared to the last year, inflow has increased insignificantly (by $1.3 \%$ ) and outflow - by $13.7 \%$. These numbers one might understand as outflow growth from Russia, which is due to crisis and other negative factors, but this is not quite so. Major migration outflow is due to delayed effect of change in methodology of long-term migration count undertaken in 2011. Foreign nationals arriving to Russia and receiving registration for 9 and more months were considered as migration inflow, which originally produced an effect of inflow growth (in 2011-2012). By now, if and when registration term expires of foreign nationals who arrived during previous years posted outflow increase. Currently registration terminates of migrants who arrived prior to the crisis (in 2012-2014). Migration statistics registers this as an outflow from the country.

Positive migration balance of Russia's population in 2015 contracted in comparison with 2014 and constituted 246,000 persons. During previous years, it remained at such low level solely in $2002^{2}$ (corrected to re-count of 2010 census results; without their count it was below this level during 20012006. At the same time, migration from the post-Soviet countries was explicitly understated ${ }^{3}$ ). Apparently, the potential of migration gain in Russia from the post-Soviet countries has run dry despite somewhat easing of Russia's policy towards migrants inflow: widening of the Program of support for voluntary migration of compatriots residing abroad, implementation of simplified procedures for obtaining Russian citizenship for native speakers of Russian, etc. Among far abroad countries, there are no feasible significant partners for long-term migration. Even Chinese nationals predominantly arrive to Russia as temporary labor migrants.

The role of Ukraine has sharply increased following the events of the beginning- mid-2014 in relation to migrant inflow from CIS member states. Owing to the fact that Ukrainian nationals stay in Russia without registration

1 This paper was originally published in Online Monitoring of Russia's Economic Outlook No.6(24).

2 Demography Yearbook of Russia - 2015. Statistical digest. Moscow, 2015. Table 1.2.

3 Russia's Population 2012. Twentieth Annual Demographic Report. Ed in Chief A.G. Vishnevsky. Moscow. HSE Publishers, 2014. pp. 343-345. 
and intend to prolong their stay for indefinitely long period, the potential for growth ('on paper') of registered long-term migration from that country to Russia remains. As of the beginning of 2016, 311,000 Ukrainian nationals received temporary asylum in Russia.

In 2015, Ukraine ensured around $60 \%$ of net migration to Russia. Without the contribution of that country, the net migration to Russia would have been less than 100,000 persons, the lowest for the entire post-Soviet period.

The role of the Central Asian countries in migration gain has fallen significantly. With respect to Uzbekistan, there is a migration loss by over 20,000 persons in 2015. Main reason is above mentioned change in the migrants registration procedure (put off departures growth). However, actual decline in the number of arrivals from those countries has also affected the situation. The resource for long-term migration to Russia from those countries is not limitless, which we mentioned on several occasions before, moreover, when it amounted to compatriots' migration residing abroad. The majority of them have already moved to Russia during almost quarter of century life of our countries and part of them have adapted to life in their countries.

At consistently low level remains migration gain from far abroad countries - 8,200 persons in 2015 against 10,100 in 2014 and is mainly owing to Georgia, Abkhazia and the Baltic states (all those countries are recently referred as far abroad countries). There are no reliable figures regarding departure of Russian nationals for an indefinite period to EU countries, US, Israel and other. According to estimates released by those countries, the number of departures from Russia is at least underestimated by $2-3$ fold $^{1}$.

In 2015, practically ran dry the volume growth of internal long-term migration. The number of internal migrants went up to $4,135,000$ persons up $1.5 \%$ against 2014. It is of interest that it took a lot of time to adapt to the new methodology of migrants count (2011, we mentioned it above) and significant twofold growth of the number of migrants in 2011-2013 was most likely determined by this factor. Certain influence was exerted by easing of registration procedure at place of residence, in particular, submission of documents to multifunctional center (for example, in Moscow - single point of contact) and reduction of the number of unreasonable demands at receiving registration including norms of leaving space per person².

Centers, which attract migrants, change very little. Undoubtedly, Moscow and the Moscow region retain leading positions. In 2015, they increased their population owing to migration by 200,000 persons (more than $1 \%$ ). Moreover, over $80 \%$ of that growth was accounted to internal migration. Owing to migration significantly grows population of the Krasnodar Krai 58,000 persons, St. Petersburg and the Leningrad region $-12,000$ persons. There is a new center for attracting migrants - the Crimea federal okrug, whose net migration constituted 34,000 persons.

Regions of Far Easter, Siberian, Volga, and North-Caucasus federal okrugs continued loosing population due to migration. In 2015, 'leaders' among migration outflow remained Republic of Dagestan (13,000 persons), YamalNenets AO (12,000 persons), the Komi Republic, and Arkhangelsk region (8,000 persons each).

1 Denisenko $M$. If we take a look from the other shore. Migration XXI century, No. 1(4), January-February 2011, pp.36-39.

2 It is not the case of the so called "rubber apartments" but about the registration of actually living Russian nationals in living quarters. 
Observed in 2015 trend of long-term migration do not allow to talk about a serious impact of the crisis on its scale and directions compared to temporary migration these flows are inactive.

\section{Temporary migration}

The number of all foreign nationals temporarily residing on the territory of Russia has been constantly falling during nearly a year - since spring 2015, breaking customary seasonal character of this indicator (Fig. 1). At the same time, is the beginning of 2015 was characterized by maximum number of foreign nationals compared to recent years $(10.9 \mathrm{~m}$ as of the end of 2015 , which is by $4 \%$ more than the same date 2014 and by $9 \%$ more against 2013), then by the end of the year the indicator fell to the minimum $-9.9 \mathrm{~m}$ as of the end of December (by $11 \%$ less than in

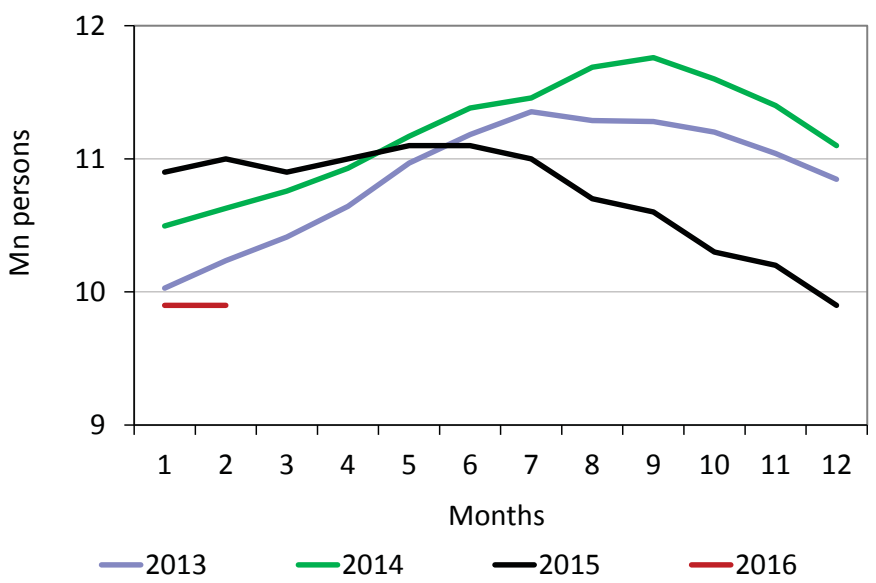

Fig. 1. Number of foreign nationals on Russia's territory as of the end of month, million persons, 2013-2016 2014 , and by $9 \%$ less on 2013). The same trend, it seems, will continue in 2016. For example, for 2 first months the number of foreign nationals actually remained at the level of late 2015. In absolute terms, contraction for a year constituted 1.1m (end of February 2016 against February 2015), which looks significant but not catastrophic.

Natives of CIS countries still constitute the majority of foreign nationals in Russia. Their share in early March 2016 constituted $86 \%$ or $8.5 \mathrm{~m}$ persons (Table 1).

Table 1

STAY OF FOREIGN NATIONAL FROM CIS COUNTRIES IN RUSSIA, PERSONS

\begin{tabular}{|l|c|c|}
\hline & As of March 4, 2015 & As of March 1, 2016 \\
\hline Azerbaijan & 562787 & 520844 \\
\hline Armenia & 484892 & 469481 \\
\hline Belorussia & 529953 & 650809 \\
\hline Kazakhstan & 626594 & 624512 \\
\hline Kirgizia & 523221 & 572759 \\
\hline Moldova & 557592 & 488616 \\
\hline Tajikistan & 963489 & 862914 \\
\hline Uzbekistan & 2131300 & 1764468 \\
\hline Ukraine & 2552844 & 2507677 \\
\hline CIS, total & 8932672 & 8462080 \\
\hline
\end{tabular}

Sources: FMS of Russia, Central Bank of Data on Foreign Nationals Counts.

During the year, the number of CIS nationals in Russia declined by $5 \%$, but the pattern changed differently for various countries. The number of nationals from EEU (Kazakhstan, Belorussia, Armenia, and Kirgizia) has been growing owing to simplified employment procedure (no authorization documents are required) and migration registration in $\mathrm{RF}^{1}$.

1 Small reduction (by 3\%) of Armenian nationals registered during recent months most likely indicates the fact that migration potential of this country has run dry. However, it does 
At the same time, the number of foreign nationals from other CIS countries was contracting. It was most noticeable in relation to main contributing countries of labor migrants to Russia - Uzbekistan and Tajikistan (for a year, reduction amounted to 15\%). Remaining high throughout 2016, the number of temporary arriving Ukrainian nationals at the beginning of 2016 began falling although not so fast. Taking into account introduced from November 2015, restrictions regarding stay of Ukrainian nationals in Russia, one can expect further contraction of their numbers (unless there is force majeure).

Significantly higher quantitative shifts happened regarding numbers of foreign national arriving from far-abroad countries, especially from advanced countries: the number of nationals from EU countries fell by $40 \%$ during the year (over 2 years - by $60 \%$ ). The number of nationals from such countries as US, Great Britain and Spain fell by around 70\% during the year and by over $80 \%$ in the course of 2 years (Table 2). The number of tourists fell most of all (although those arriving on business trips and study tours also reduced). According to data released by the FMS of Russia, the number of arrivals with tourist purposes EU nationals at the beginning of March was 2.5fold more that in March 2016.

Table 2

NUMBER OF FOREIGN NATIONALS FROM CERTAIN EU COUNTRIES AND US IN RUSSIA, PERSONS

\begin{tabular}{|l|c|c|c|}
\hline & As of March 2, 2014 & As of March 4, 2015 & As of March 1, 2016 \\
\hline Germany & 347094 & 238293 & 110706 \\
\hline Spain & 76576 & 45445 & 14635 \\
\hline Italy & 75173 & 52541 & 27577 \\
\hline Great Britain & 178186 & 109930 & 28311 \\
\hline France & 64886 & 50622 & 33446 \\
\hline EU as a whole & 1177366 & 811696 & 483683 \\
\hline USA & 220275 & 141115 & 45625 \\
\hline
\end{tabular}

Sources: FMS of Russia, Central Bank of Data on Foreign Nationals Counts.

The number of foreign labor migrants (judging by indicated at the entry to Russia purpose of visit as 'employment') as of beginning of March 2016 amounted to $3.9 \mathrm{~m}$ persons, which exceed the March 2015 indicator by 5\% (approximately by 200,000 ). However, most likely, this does not reveal the real growth of the number of labor migrants. Simply, the majority of arrivals started to indicate work as the purpose of entry because with this is impossible to officially process authorization documents for employment. If we count migrants in working age entering Russia on private purposes but working unofficially, then the total estimate will be somewhat below the level of March 2015 (by 4-5\%) and will not exceed 6-6.5m persons ${ }^{1}$.

Amid contraction of supply on the Russian labor market and decrease of real wages accompanied by radical changes in the migration legislation since the beginning of 2015, there remain difficulties for legalization of foreign workers. For example, the number of those who obtained authorization documents for work in Russia during 2 months of 2016 happened to be less

not refer to the number of arrivals for employment.

1 If we count all arrivals with private purposes excluding old age people and children as labor migrants. In reality, significant share stay in Russia on personal purposes. 
by $60 \%$ than during the same period of 2014 , although somewhat exceeded indicators of early 2015 (Table 3). Overall, 1.7 foreign nationals had effective documents for work as of early March ${ }^{1}$.

Table 3

\section{PROCESSING OF AUTHORIZATION DOCUMENTS FOR WORK FOR MIGRANTS} IN RUSSIA, PERSONS

\begin{tabular}{|c|c|c|c|}
\hline & $\begin{array}{c}\text { January- } \\
\text { February } 2016\end{array}$ & $\begin{array}{c}\text { January- } \\
\text { February } 2015\end{array}$ & $\begin{array}{c}\text { January- } \\
\text { February } 2014\end{array}$ \\
\hline Work permits for foreign nationals* & 8518 & 29320 & 118682 \\
\hline $\begin{array}{l}\text { Work permits for quali- } \\
\text { fied specialists * }\end{array}$ & 985 & 1423 & 2897 \\
\hline $\begin{array}{l}\text { Work permits for highly } \\
\text { qualified specialists }\end{array}$ & 2695 & 3490 & 4488 \\
\hline Work patents** & 126983 & 79185 & 223322 \\
\hline Total & 139181 & 113418 & 349389 \\
\hline
\end{tabular}

* Since 1 January 2015 issued solely to foreign national from visa-free regime countries.

** Since 1 January 2015 issued to visa-free foreign nationals employed both by individuals and legal entities.

Sources: FMS of Russia, 1-RD form.

However, already amid contraction of official employment, regional budgets received significant revenues due to increased in 2015 monthly payment for work patents (personal income tax in terms of fixed advance payment): $\mathrm{Rb} 33.3 \mathrm{bn}$ for 2015 compared to Rb 17.9bn for 2014.

1 Among the number of lega foreign nationals who received offcial documents for work in Russia should also be around 300,000-400,000 foreign nattionals who officially work without such documents and who are nationals of EEU member states; foreign nationals who havграждан, имеющих разрешение на временное проживание в permits for temporary residence; refugees and those who received temporary asylum. 